\title{
ADAPTASI PENYELENGGARAAN PEMERINTAH KECAMATAN PASCA IMPLEMENTASI KEBIJAKAN PENATAAN KECAMATAN DI KOTA PEKANBARU (Studi Kasus Pada Kecamatan Tuahmadani)
}

\author{
${ }^{1}$ Hafizh Ayyasy Habibi, ${ }^{2}$ Hasim As'ari \\ 1, 2 Program Studi IImu Administrasi Publik, Fakultas IImu Sosial dan IImu Politik, Universitas Riau \\ hafizhayyasy23@gmail.com, hasim_asari99@yahoo.co.id \\ Pekanbaru, 28293, Indonesia
}

\begin{abstract}
The sub-district structuring policy is a new policy that must be implemented by all actors involved. This policy is based on the Pekanbaru City Regional Regulation Number 2 of 2020 concerning District Arrangements. In its implementation, adaptation is needed so that the administration of the new sub-district government can run well. However, it is known that there are still problems in the adaptation process carried out. This study aims to see the adaptation process carried out by the Tuahmadani District in the administration of its government after the sub-district structuring policy is implemented. By using qualitative research methods with data collection techniques by observation, interviews, and documentation. The results of this study indicate that the adaptation carried out by the Tuahmadani District has been going quite well but in its implementation there are still obstacles and obstacles so that the adaptation process carried out has not run optimally.
\end{abstract}

Keywords: Adaptation; District Arrangement; Implementation

\begin{abstract}
Abstrak
Kebijakan penataan kecamatan merupakan kebijakan baru yang harus diimplementasikan oleh semua aktor yang terlibat. Kebijakan ini berdasarkan Peraturan Daerah Kota Pekanbaru Nomor 2 Tahun 2020 tentang Penataan Kecamatan. Dalam implementasinya, sangat diperlukan adaptasi agar penyelenggaraan pemerintah kecamatan baru bisa berjalan dengan baik. Namun diketahui, masih ditemukan adanya masalah dalam proses adaptasi yang dilakukan. Penelitian ini memiliki tujuan untuk melihat proses adaptasi yang dilakukan Kecamatan Tuahmadani dalam penyelenggaraan pemerintahannya pasca kebijakan penataan kecamatan diimplementasikan. Dengan menggunakan metode penelitian kualitatif dengan teknik pengumpulan data secara observasi, wawancara, dan dokumentasi. Hasil penelitian ini menunjukkan bahwa adaptasi yang dilakukan oleh Kecamatan Tuahmadani sudah berjalan cukup baik namun dalam pelaksanaannya masih ditemui hambatan dan kendala sehingga proses adaptasi yang dilaksanakan belum berjalan secara maksimal.
\end{abstract}

Kata Kunci: Adaptasi; Implementasi; Penataan Kecamatan,

Open Access at:http://ojs.uho.ac.id/index.php/PUBLICUHO/index

Journal Publicuho is licensed under a Creative Commons Attribution 4.0 International License. 


\section{Journal Publicuho}

ISSN2621-1351 (online), ISSN 2685-0729 (print)

Volume 4 Number 4 (November - January), (2021) pp. 1254-1271 Accredited SINTA SK.NOMOR 28/E/KPT/2019 Open Access at:http://ojs.uho.ac.id/index.php/PUBLICUHO/index $\quad$ DOl: http://dx.doi.org/10.35817/jpu.v4i4.22614

\section{PENDAHULUAN}

Kebijakan Penataan Kecamatan di Kota Pekanbaru di implementasikan berdasarkan Peraturan Daerah Kota Pekanbaru Nomor 2 Tahun 2020 tentang Penataan Kecamatan. Adapun tujuan dari kebijakan ini dalam rangka penataan wilayah daerah Kota Pekanbaru untuk meningkatkan pelayanan, pemberdayaan, dan kesejahteraan masyarakat. Sejalan dengan pernyataan Syadzily (2019:5) bahwa penataan daerah merupakan upaya untuk menata dan mengatur penyelenggaraan pemerintahan agar fungsi-fungsi pemerintahan dapat berjalan dengan efektif dan efisien. Fungsi-fungsi tersebut antara lain meliputi fungsi regulasi, pelayanan publik dan pembedayaan masyarakat. Bentuk dari penataan kecamatan ini adalah pemekaran kecamatan yang salah satu kecamatan hasil pemekarannya berdasarkan kebijakan tersebut adalah Kecamatan Tuahmadani yang merupakan pemekaran dari kecamatan induknya yakni Kecamatan Tampan. Adanya implementasi kebijakan penataan kecamatan ini mengakibatkan banyak perubahan dan fenomena yang terjadi di lingkungan Kecamatan Tuahmadani. Hal ini sejalan dengan pernyataan Sadler dalam Siahaan (2012:42) bahwa perubahan pada organisasi salah satunya disebabkan oleh kebijakan publik baru dan perubahan kebijakan publik. Smith (1973:204) menyebutkan bahwa pemerintah membuat kebijakan yang tujuannya adalah untuk menciptakan perubahan atau perbaikan dalam masyarakat sebagai sebuah target group. Dalam hal ini, sebuah target group diharapkan agar mampu beradaptasi dengan berbagai pola perilaku baru dengan kebijakan yang telah dilaksanakan. Perubahan yang terjadi diantaranya adalah perubahan dalam struktur organisasi Kecamatan Tuahmadani, adanya inovasi baru dalam hal teknologi peningkatan pelayanan berbentuk aplikasi yang belum dilaksanakan secara maksimal, kurangnya ketersediaan infrastruktur dan sarana prasarana di dalam Kantor Camat Tuahmadani yang mempengaruhi kualitas pelayanan yang diberikan kepada masyarakat dan kurangnya ketersediaan pegawai kecamatan dalam penyelenggaraan pemerintahan. Dari fenomena yang disebutkan tersebut, maka dalam penyelenggaraan pemerintahannya, Kecamatan Tuahmadani perlu melakukan adaptasi dalam penyelenggaraan pemerintahannya pasca kebijakan tersebut di implementasikan.

Robbins dalam Maksudi (2018:42) mengatakan bahwa organisasi diasumsikan sebagai organisme hidup, seperti tanaman, binatang atau manusia yang lahir, tumbuh dan berkembang serta membutuhkan makanan bagi kelangsungan hidupnya. Dari pemahaman ini, jelas organisasi harus memiliki kemampuan adaptasi terhadap lingkungan dimana ia berada. Karena lingkungan merupakan asupan energi bagi organisasi agar dapat mempertahankan kelangsungan hidupnya, sehingga dalam teori organisasi modern organisasi dikonsepsikan sebagai sistem. Selanjutnya Kaufman dalam Joaquin (2009:250) 
ISSN2621-1351 (online), ISSN 2685-0729 (print

Volume 4 Number4 (November - January), pp.1254-1271

Hafizh Ayyasy Habibi, Hasim As'ari DOI: http://dx.doi.org/10.35817/jpu.v4i4.22614

memandang organisasi sebagai organisme yang hidup dalam perubahan lingkungan dimana mereka harus bereaksi dengan melakukan adaptasi untuk bertahan hidup. Jika lingkungan menjadi lebih mengancam atau lebih tidak pasti, maka organisasi harus berubah dengan cara melakukan adaptasi untuk menghadapi ketidakpastian atau ancaman tersebut. Sejalan dengan hal tersebut, Nurasa (2013:82) mengatakan bahwa konsep adaptasi merupakan hasil adopsi dari ilmu alam, yaitu ilmu biologi, yang menjelaskan reaksi dari suatu organisme untuk dapat bertahan terhadap tuntutan dan tekanan perubahan lingkungannya (mekanisme survival strategy). Dengan demikian, pengertian adaptasi dapat dijelaskan sebagai suatu tindakan organisme untuk melakukan perubahan struktur dalam rangka memelihara keadaan setimbang terhadap perubahan lingkungan yang dinamis, sehingga akan membentuk suatu komposisi struktur lingkungannya yang saling bersinergis. Disamping itu, Sarta, Durand, \& Vergne, (2021:46) mendefinisikan adaptasi sebagai pengambilan keputusan yang disengaja yang dilakukan oleh anggota organisasi, yang mengarah pada tindakan yang dapat diamati yang bertujuan untuk mengurangi jarak antara organisasi dan lingkungan ekonomi dan kelembagaannya. Robbins (2001:543) menyebutkan adaptasi organisasi dapat dikelompokkan ke dalam empat kategori, yaitu perubahan struktur, perubahan teknologi, perubahan penataan fisik, dan perubahan sumber daya manusia. Dari keempat komponen tersebut, peneliti menjadikan komponen-komponen tersebut sebagai acuan untuk melihat proses adaptasi yang dilakukan oleh Kecamatan Tuahmadani dalam penyelenggaraan pemerintahannya pasca kebijakan penataan kecamatan di implementasikan.

Penelitian ini memiliki tujuan untuk mengetahui bagaimana proses adaptasi yang dilakukan oleh Kecamatan Tuahmadani dalam hal penyelenggaraan pemerintah kecamatan pasca implementasi kebijakan penataan kecamatan di Kota Pekanbaru, selain itu penelitian ini juga dilakukan untuk mengidentifikasi hambatan yang dihadapi dalam proses adaptasi penyelenggaraan pemerintah kecamatan pasca implementasi kebijakan penataan kecamatan di Kota Pekanbaru serta untuk mengidentifikasi upaya yang dilakukan oleh Kecamatan Tuahmadani dalam mengatasi hambatan pada proses adaptasi penyelenggaraan pemerintah kecamatan pasca implementasi kebijakan penataan kecamatan di Kota Pekanbaru.

\section{METODOLOGI}

Penelitian ini menggunakan metode penelitian kualitatif, menurut Creswell (2015:59) penelitian kualitatif adalah metode penelitian yang dimulai dari asumsi, lensa penafsrian/teoretis, dan studi tentang permasalahan riset yang meneliti bagaimana individu atau kelompok memaknai permasalahan sosial atau kemanusiaan. Alasan menggunakan metode kualitatif agar peneliti dapat lebih mendalam melihat adaptasi penyelenggaraan 


\section{Journal Publicuho}

ISSN2621-1351 (online), ISSN 2685-0729 (print)

Volume 4 Number 4 (November - January), (2021) pp. 1254-1271 Accredited SINTA SK.NOMOR 28/E/KPT/2019 Open Access at:http://ojs.uho.ac.id/index.php/PUBLICUHO/index $\quad$ DOI: http://dx.doi.org/10.35817/jpu.v4i4.22614

pemerintah Kecamatan Tuahmadani pasca implementasi kebijakan penataan kecamatan dengan pengumpulan data metode penelitian kualitatif.

Pendekatan yang digunakan dalam penelitian ini adalah pendekatan studi kasus, menurut Creswell (2015:135) pendekatan studi kasus adalah pendekatan kualitatif dimana penelitinya mengeksplorasi kehidupan nyata, sistem terbatas kontemporer (kasus) atau beragam sistem terbatas (berbagai kasus), melalui pengumpulan data yang detail dan mendalam yang melibatkan beragam sumber informasi seperti pengamatan, wawancara, bahan audiovisual, dan dokumen serta berbagai laporan. Dalam hal ini peneliti mengumpulkan data terkait adaptasi penyelenggaraan pemerintah Kecamatan Tuahmadani pasca implementasi kebijakan penataan kecamatan.

\section{HASIL DAN PEMBAHASAN}

Menurut Dunn (dalam La Ode Muhammad Elwan, S., \& Pramusinto, A. 2011), analisis kebijakan adalah aktivitas intelektual dan praktis yang ditujukan untuk menciptakan, secara kritis menilai, dan mengkomunikasikan pengetahuan dan dalam proses kebijakan. Analisis kebijakan adalah disiplin ilmu sosial terapan yang menggunakan berbagai metode pengkajian multiple dalam konteks argumentasi dan debat politik untuk menciptakan, secara kritis menilai, dan mengkomunikasikan pengetahuan yang relevan tentang kebijakan.(Muhammad Elwan, 2020)

Demikian halnya menurut Jones (1991) dalam La Ode Muhammad Elwan, (2011: 18) menjelaskan bahwa Implementasi kebijakan mudah dimengerti secara teoritik dan konseptual, namun tidak senantiasa demikian dalam bentuknya yang kongkrit, karena pelaksanaannya secara nyata bukanlah sesuatu yang mudah (Supriadin et al., 2020)

\section{Proses Adaptasi Dalam Penyelenggaraan Pemerintah Kecamatan Tuahmadani Pasca Implementasi Kebijakan Penataan Kecamatan}

Adaptasi organisasi adalah sebuah proses perubahan suatu organisasi di mana organisasi berupaya mengatasi dan mempertimbangkan tuntutan lingkungan serta melakukan penyesuaian yang diperlukan organisasi untuk menjaga eksistensi dari organisasi tersebut dalam mencapai tujuannya. Proses adaptasi dalam penelitian ini dilihat berdasarkan teori adaptasi menurut Robbins (2001:543) dimana dalam proses adaptasi organisasi harus didukung oleh seluruh komponen organisasi. Adapun komponen-komponen adaptasi organisasi tersebut adalah perubahan struktur, perubahan teknologi, perubahan penataan fisik, dan perubahan sumber daya manusia. Berikut merupakan hasil penelitian yang telah dilakukan:

\section{Perubahan Struktur}

Implementasi kebijakan penataan kecamatan menyebabkan terjadinya perubahan struktur dalam kecamatan baru akibat dari pemekaran kecamatan, salah satunya adalah 
ISSN2621-1351 (online), ISSN 2685-0729 (print

Volume 4 Number4 (November - January), pp.1254-1271 DOI: http://dx.doi.org/10.35817/jpu.v4i4.22614

Kecamatan Tuahmadani. Perubahan struktur yang terjadi adalah kelurahan yang dibawahi oleh kecamatan baru tersebut yang mana kelurahan adalah organisasi perangkat daerah yang bertanggung jawab kepada pemerintah kota melalui kecamatan.

Sebelum adanya kebijakan penataan kecamatan, kecamatan induk dari Kecamatan Tuahmadani yakni Kecamatan Tampan memiliki struktur sebagai berikut:

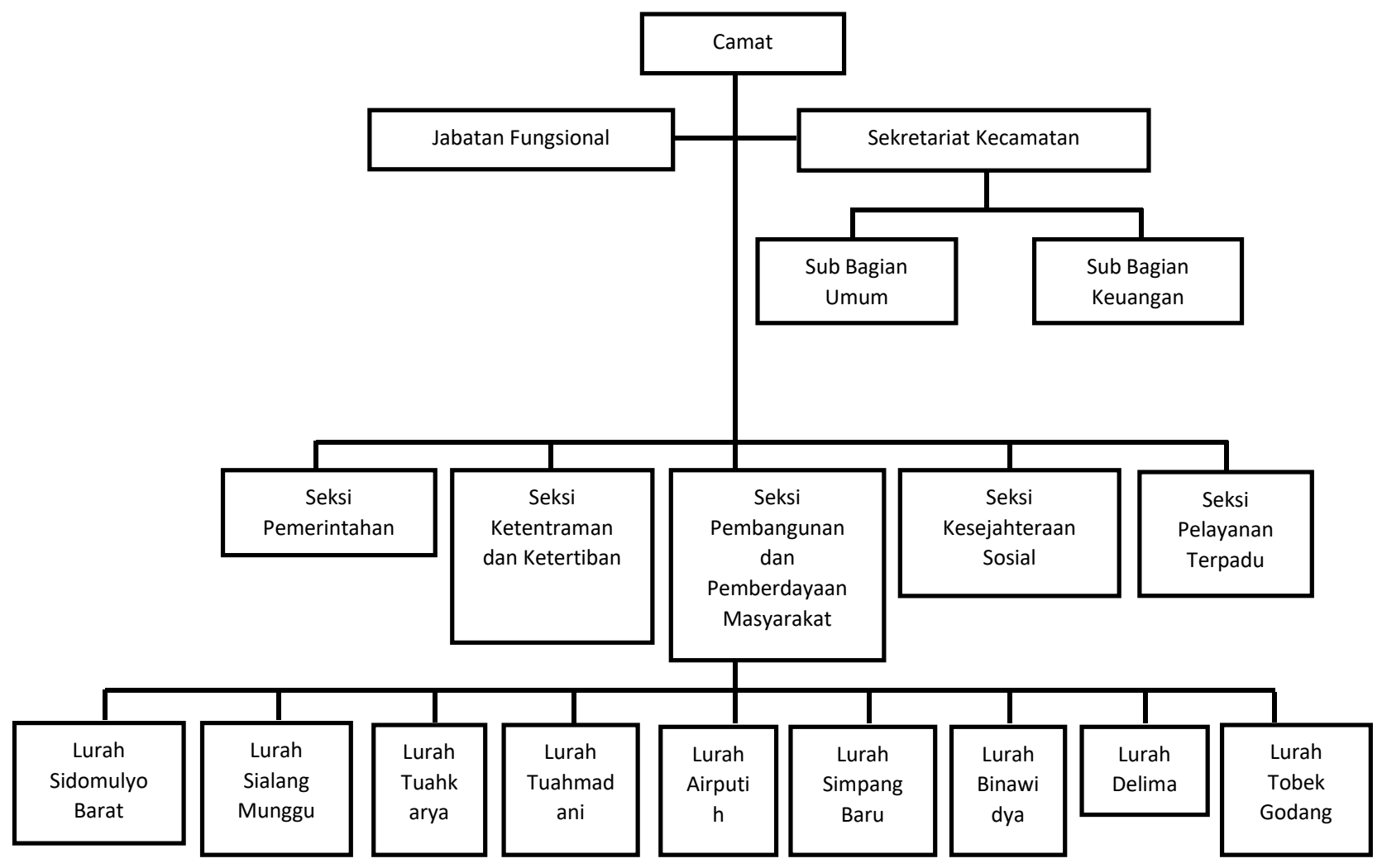

Gambar 1. Struktur Kecamatan Tampan Tahun 2020 Sumber: Lampiran Perda Kota Pekanbaru Nomor 09 Tahun 2016

Dari gambar diatas, diketahui bahwasanya jumlah kelurahan di Kecamatan Tampan sebelum dimekarkan adalah 9 (Sembilan) kelurahan, diantaranya adalah Kelurahan Sidomulyo Barat, Kelurahan Sialang Munggu, Kelurahan Tuahkarya, Kelurahan Tuahmadani, Kelurahan Airputih, Kelurahan Simpang Baru, Kelurahan Binawidya, Kelurahan Delima, Kelurahan Tobek Godang.

Namun, setelah Kecamatan Tampan dimekarkan menjadi Kecamatan Tuahmadani berdasarkan Peraturan Daerah Kota Pekanbaru Nomor 2 Tahun 2020 tentang Penataan Kecamatan, struktur Kecamatan Tuahmadani berubah menjadi sebagai berikut: 


\section{Journal Publicuho}

ISSN2621-1351 (online), ISSN 2685-0729 (print)

Volume 4 Number 4 (November - January), (2021) pp. 1254-1271 Accredited SINTA SK.NOMOR 28/E/KPT/2019 Open Access at:http://ojs.uho.ac.id/index.php/PUBLICUHO/index $\quad$ DOl: http://dx.doi.org/10.35817/jpu.v4i4.22614

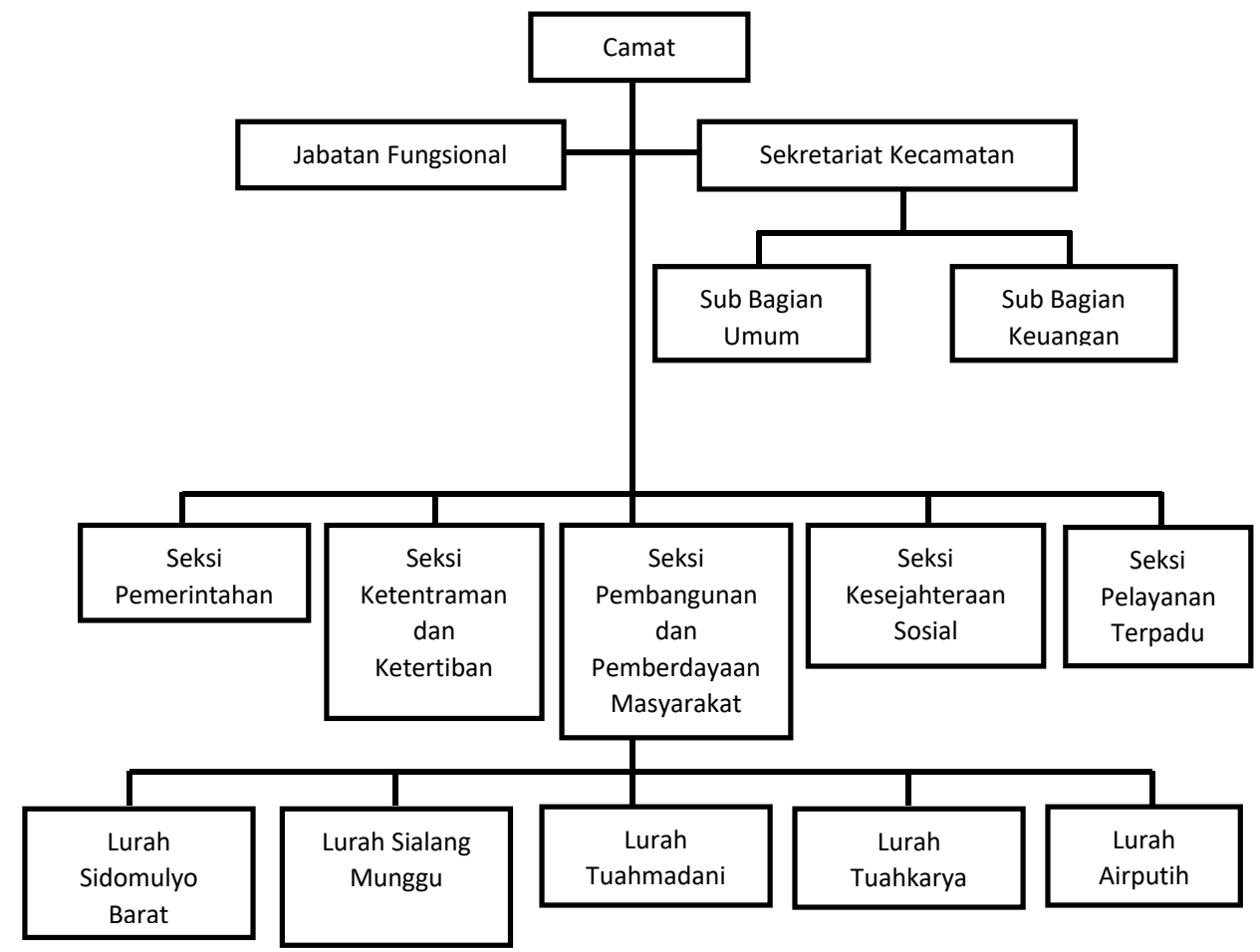

Gambar 2. Struktur Kecamatan Tuahmadani Tahun 2021 Sumber: Olahan peneliti, 2021

Dari gambar diatas, dapat dilihat bahwasanya dalam struktur organisasi kecamatan terjadi perubahan dalam kelurahan yang dibawahi oleh Kecamatan Tuahmadani. Namun tidak terjadi perubahan pada struktur atau susunan organisasi kecamatannya. Struktur kecamatan nya tetap dengan penamaan jabatan dan seksi-seksinya. Kecamatan induk yakni Kecamatan Tampan awalnya membawahi 9 (sembilan) kelurahan. Setelah adanya kebijakan penataan kecamatan dimana Kecamatan Tampan dimekarkan menjadi Kecamatan Tuahmadani, terjadi perubahan dimana Kecamatan Tuahmadani membawahi 5 (lima) kelurahan, diantaranya adalah Kelurahan Sidomulyo Barat, Kelurahan Sialang Munggu, Kelurahan Tuahmadani, Kelurahan Tuahkarya, dan Kelurahan Airputih.

Hal ini juga didukung oleh wawancara yang peneliti lakukan dengan informan yakni Sekretaris Camat Tuahmadani yang mengatakan bahwa dalam kebijakan penataan kecamatan ini, Kecamatan Tuahmadani mengambil 5 (lima) kelurahan dari Kecamatan induk yaitu Kecamatan Tampan yakni Kelurahan Sidomulyo Barat, Sialang Munggu, Tuah Karya, Tuah Madani dan Air Putih. 5 (lima) kelurahan tersebut yang sebelumnya bertanggung jawab membantu Kecamatan Tampan berubah menjadi bertanggung jawab membantu Kecamatan Tuahmadani.

Dalam hal pembentukan struktur, Robbins dalam Sunandar (2012:407) menjelaskan 6 (enam) unsur yang perlu diperhatikan dalam pembentukan struktur organisasi, yakni sebagai berikut: 
ISSN2621-1351 (online), ISSN 2685-0729 (print

Volume 4 Number4 (November - January), pp.1254-1271

DOI: http://dx.doi.org/10.35817/jpu.v4i4.22614

Hafizh Ayyasy Habibi, Hasim As'ari

1. Spesialisasi atau pembagian tenaga kerja. Merupakan pemecahan suatu alur penyelesaian pekerjaan menjadi sejumlah langkah penyelesaian yang diselesaikan dengan kualifikasi tertentu.

2. Departementalisasi, dapat didasarkan pada kesamaan kelompok pekerjaan maupun berdasarkan teritori agar tugas dapat dikoordinasikan.

3. Rantai komando, merupakan alur perintah dan kewenangan berkaitan dengan tanggung jawab dari tingkatan-tingkatan dalam suatu organisasi.

4. Rentang kendali, menentukan banyaknya tingkatan dan manajer yang harus dimiliki oleh suatu organisasi.

5. Sentralisasi dan desentralisasi, merupakan suatu cara pengambilan keputusan berdasarkan kewenangan manajerial.

6. Formalisasi, merupakan suatu tingkatan pekerjaan dalam suatu organisasi yang dibakukan berdasarkan aturan.

Oleh karena itu, struktur organisasi perlu di desain dengan baik karena struktur organisasi berisi sumber daya manusia atau pegawai yang bekerja secara individu atau secara berkelompok dengan mengikuti arahan pimpinan untuk mencapai tujuan organisasi atau dapat dikatakan bahwa struktur organisasi sebagai alat bagi organisasi untuk mengkoordinir anggota organisasi agar mencapai tujuan dan harapan dari organisasi tersebut.

Bersamaan dengan hal tersebut, Peraturan Wali Kota Pekanbaru Nomor 233 Tahun 2020 tentang Kedudukan, Susunan Organisasi, Tugas dan Fungsi serta Tata Kerja Kecamatan di lingkungan Pemerintah Kota Pekanbaru menjelaskan bahwa struktur organisasi atau susunan organisasi kecamatan terdiri dari:

a. Camat.

b. Sekretariat Kecamatan, membawahi: Sub bagian umum dan Sub bagian keuangan

c. Seksi Pemerintahan.

d. Seksi Ketentraman dan Ketertiban.

e. Seksi Pembangunan dan Pemberdayaan Masyarakat.

f. Seksi Kesejahteraan Sosial

g. Seksi Pelayanan Terpadu.

h. Kelompok Jabatan Fungsional.

Dalam hal ini, peneliti menilai bahwa struktur organisasi kecamatan yang telah diatur dalam Peraturan Wali Kota Pekanbaru Nomor 233 Tahun 2020 tentang Kedudukan, Susunan Organisasi, Tugas dan Fungsi serta Tata Kerja Kecamatan di lingkungan Pemerintah Kota Pekanbaru memiliki kesesuaian dengan teori Robbins tentang 6 (enam) unsur yang perlu diperhatikan dalam pembentukan struktur yang telah dijabarkan diatas. Kesesuaian yang peneliti maksud dapat dijelaskan sebagai berikut: 


\section{Journal Publicuho}

ISSN2621-1351 (online), ISSN 2685-0729 (print)

Volume 4 Number 4 (November - January), (2021) pp. 1254-1271 Accredited SINTA SK.NOMOR 28/E/KPT/2019 Open Access at:http://ojs.uho.ac.id/index.php/PUBLICUHO/index $\quad$ DOI: http://dx.doi.org/10.35817/jpu.v4i4.22614

1. Spesialisasi atau pembagian tenaga kerja. Merupakan pemecahan suatu alur penyelesaian pekerjaan menjadi sejumlah langkah penyelesaian yang diselesaikan dengan kualifikasi tertentu. Dalam hal ini, di struktur Kecamatan Tuahmadani memiliki 5 (lima) seksi yang bekerja sesuai dengan tugas dan fungsinya masing-masing dan memiliki wewenang terhadap penyelesaian segala tugas dan permasalahan yang telah diatur.

2. Departementalisasi, dapat didasarkan pada kesamaan kelompok pekerjaan maupun berdasarkan teritori agar tugas dapat dikoordinasikan. Dalam hal ini, Kecamatan Tuahmadani yang memilki 5 (lima) seksi tersebut, memiliki pegawai/bawahannya tersendiri yang dikelompokkan kedalam seksi-seksi tersebut. Sehingga pekerjaan yang dilakukan pegawai tersebut berdasarkan teritori atau tugas dan fungsi yang telah ditetapkan sesuai seksi nya masingmasing.

3. Rantai komando, merupakan alur perintah dan kewenangan berkaitan dengan tanggung jawab dari tingkatan-tingkatan dalam suatu organisasi. Dalam hal ini, Kecamatan Tuahmadani memiliki pemimpin yang biasa dipanggil Camat. Berdasarkan arahan dan instruksi, Camat bisa memberikan arahan/instruksi kepada seksi-seksi nya, lalu dari seksi-seksi tersebut memberikan arahan/instruksi kepada pegawai/bawahannya dalam bekerja. Selain itu, Kecamatan Tuahmadani membawahi 5 (lima) kelurahan di dalam wilayahnya, sehingga Camat Tuahadani juga bisa memberikan arahan/instruksi kepada kelurahan terkait proses penyelenggaraan pemerintahan.

4. Rentang kendali, menentukan banyaknya tingkatan dan manajer yang harus dimiliki oleh suatu organisasi. Dalam hal ini, Kecamatan Tuahmadani memiliki 3 (tiga) tingkatan, yakni Camat, Sekretaris Camat, dan Kepala Seksi.

5. Sentralisasi dan desentralisasi, merupakan suatu cara pengambilan keputusan berdasarkan kewenangan manajerial. Dalam hal ini, pengambilan keputusan puncak merupakan wewenang dari Camat Tuahmadani. Dan pengambilan keputusan mengenai tugas dan fungsi dari seksi merupakan wewenang dari Kepala Seksi

6. Formalisasi, merupakan suatu tingkatan pekerjaan dalam suatu organisasi yang dibakukan berdasarkan aturan. Dalam hal ini, struktur atau susunan organisasi Kecamatan Tuahmadani ditetapkan berdasarkan Peraturan Walikota Pekanbaru Nomor 233 Tahun 2020 tentang Perubahan Kedudukan, Susunan Organisasi, Tugas Dan Fungsi Serta Tata Kerja Kecamatan di Lingkungan Pemerintah Kota Pekanbaru. 
ISSN2621-1351 (online), ISSN 2685-0729 (print

Volume 4 Number4 (November - January), pp.1254-1271

Hafizh Ayyasy Habibi, Hasim As'ari DOI: http://dx.doi.org/10.35817/jpu.v4i4.22614

Berdasarkan pada komponen perubahan struktur, peneliti dapat menyimpulkan bahwa organisasi dalam hal ini Kecamatan Tuahmadani memiliki kemauan atau komitmen untuk beradaptasi dengan struktur yang ditetapkan yang memiliki tugas pokok dan fungsi untuk menjalankan penyelenggaraan pemerintah kecamatan. Selain itu, struktur Kecamatan Tuahmadani yang telah ditetapkan berdasarkan Peraturan Walikota Pekanbaru Nomor 233 Tahun 2020 tentang Perubahan Kedudukan, Susunan Organisasi, Tugas Dan Fungsi Serta Tata Kerja Kecamatan di Lingkungan Pemerintah Kota Pekanbaru memiliki kesesuaian dengan 6 (enam) unsur dalam pembentukan struktur menurut Robbins.

\section{Perubahan Teknologi}

Kecamatan Tuahmadani mengalami perubahan teknologi atau pengadaan teknologi dalam hal pemberian pelayanan kepada masyarakat sebagai bentuk perwujudan dari Pekanbaru Smart City Madani. Perubahan teknologi ini adalah dengan adanya inovasi dalam upaya untuk meningkatkan pelayanan berbentuk aplikasi yang bernama SIPADU PATEN. Hal ini sejalan dengan tujuan dari implementasi Peraturan Daerah Kota Pekanbaru Nomor 2 Tahun 2020 tentang Penataan Kecamatan bahwasanya tujuan dari kebijakan ini salah satunya adalah untuk meningkatkan pelayanan kepada masyarakat.

Dapat diketahui bahwa sebelum adanya inovasi aplikasi SIPADU PATEN ini, mayoritas kecamatan dan kelurahan di Kota Pekanbaru masih menggunakan pelayanan secara manual dalam artian pelayanan yang mengharuskan masyarakat untuk datang langsung ke kantor camat atau ke kantor kelurahan. Sehingga dalam hal ini tentu banyak keluhan yang terjadi dalam mendapatkan pelayanan. Mulai dari keadaan kantor yang menjadi sempit diakibatkan masyarakat yang ramai datang ke kantor untuk mendapatkan pelayanan, jarak tempuh yang cukup jauh untuk ke kantor, serta pegawai yang kewalahan karena membludaknya masyarakat yang ingin dilayani. Sehingga kondisi tersebut menuntut adanya inovasi pelayanan yang cepat dan tepat.

Kecamatan Tuahmadani menyadari bahwa teknologi dewasa ini sangat penting dalam memudahkan segala sesuatu, dalam hal ini adalah aplikasi SIPADU PATEN hadir sebagai upaya untuk memberikan pelayanan yang cepat dan tepat. Namun dalam pelaksanaannya, aplikasi SIPADU PATEN ini belum berjalan secara maksimal. Hal ini disebabkan oleh tidak adanya sumber daya manusia atau pegawai yang memiliki skill atau kompetensi dalam menggunakan aplikasi tersebut. Hal ini diutarakan oleh Kepala Seksi Pelayanan Terpadu Kecamatan Tuahmadani bahwa kurangnya pegawai baik di kelurahan maupun kecamatan sebagai operator dalam pengoperasian aplikasi tersebut yang menjadi hambatan dan kendala dalam pelaksanaanya sehingga inovasi aplikasi ini belum berjalan dengan maksimal. Penyebab lain dari kurang maksimalnya pelaksanaan inovasi ini adalah kurangnya sosialisasi dari kecamatan kepada masyarakat sehingga masih ditemui masyarakat yang belum mengetahui adanya inovasi aplikasi SIPADU PATEN ini serta 


\section{Journal Publicuho}

ISSN2621-1351 (online), ISSN 2685-0729 (print)

Volume 4 Number 4 (November - January), (2021) pp. 1254-1271 Accredited SINTA SK.NOMOR 28/E/KPT/2019 Open Access at:http://ojs.uho.ac.id/index.php/PUBLICUHO/index ～DOI: http://dx.doi.org/10.35817/jpu.v4i4.22614

ketidakmampuan masyarakat dalam menggunakan aplikasi tersebut.

\section{Perubahan Penataan Flsik}

Perubahan penataan fisik yang terjadi di Kecamatan Tuahmadani adalah dalam bentuk pengadaan dan pembangunan kantor yang terus disempurnakan dan pemenuhan sarana dan prasarana tambahan lainnya yang terus di lengkapi di dalam lingkungan Kantor Camat Tuahmadani tersebut. Di awal kebijakan penataan kecamatan di implementasikan, Kecamatan Tuahmadani masih menumpang di salah satu ruangan yang tidak terpakai di bagian gedung SMK Dirgantara Riau yang berlokasi di Jalan Raya Pekanbaru-Bangkinang. Hal itu disebabkan ruko yang disewa oleh Kecamatan Tuahmadani sebagai kantor sementara masih belum rampung dalam pembangunan.

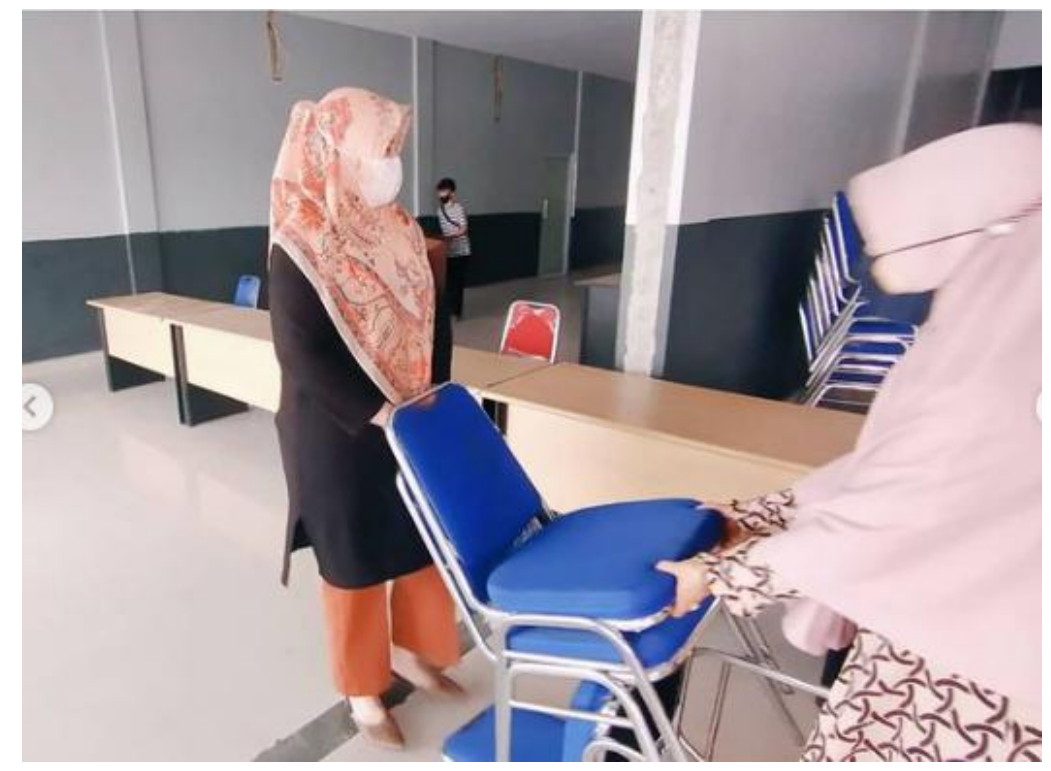

Gambar 3. Kantor Camat Tuahmadani sebelum menempati ruko sewaan Sumber: Instagram Kecamatan Tuahmadani

Dilihat dari kondisi ruangan tersebut, bahwa untuk menjadi tempat pelayanan kepada masyarakat sangat kurang nyaman. Selain itu juga dapat mempengaruhi kenyamanan pegawai dalam bekerja. Sejalan dengan pendapat Robbins, (2001:544) bahwasanya perubahan ruang dan pengaturan tata letak dalam tempat kerja dalam hal ini penataan fisik mempengaruhi kenyamanan pegawai dalam bekerja sehingga juga dapat mempengaruhi kinerja pegawai tersebut. Hal itu disebabkan karena kantor camat yang masih menumpang di sekolah yaitu SMK Dirgantara Riau sehingga segala aktivitas pegawai maupun masyarakat pasti bersamaan juga dengan aktivitas pegawai dan siswa di sekolah tersebut.

Setelah kurang lebih 2-3 bulan menumpang di gedung SMK DIrgantara Riau, Kantor Camat 
ISSN2621-1351 (online), ISSN 2685-0729 (print

Volume 4 Number4 (November - January), pp.1254-1271

Hafizh Ayyasy Habibi, Hasim As'ari DOI: http://dx.doi.org/10.35817/jpu.v4i4.22614

Tuahmadani lalu pindah ke ruko sewaan yang telah siap dibangun yang lokasinya tidak jauh dari SMK Dirgantara Riau yakni di Jalan HR. Soebrantas 14.5 .

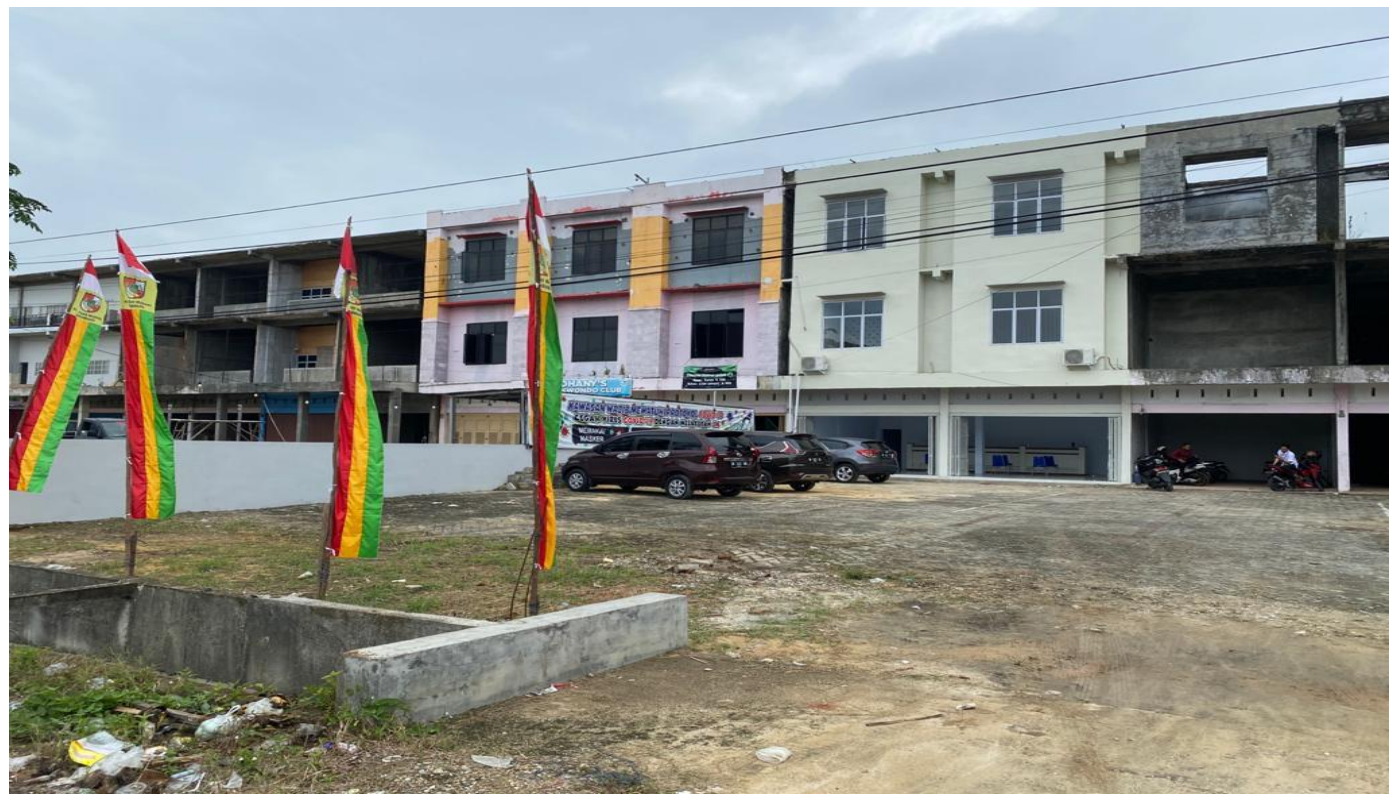

Gambar 4. Kantor Camat Tuahmadani setelah menempati ruko sewaan

Sumber: Olahan Peneliti, 2021

Dari gambar diatas, dapat dilihat bahwa ruko sewaan yang menjadi Kantor Camat Tuahmadani adalah ruko yang memiliki 2 (dua) pintu. Dari gambar tersebut juga dapat dilihat, bahwa Kantor Camat Tuahmadani dalam ruko sewaan terus melakukan penyempurnaan dalam pengisian kelengkapan sarana dan prasarana lainnya. Namun kantor tersebut sudah dapat ditempati untuk menjalankan penyelenggaraan pemerintah kecamatan. Dari wawancara yang dilakukan, peneliti mengetahui bahwa setelah di kantor baru tersebut sudah dibangun ruangan-ruangan per seksinya agar dapat ditempati oleh para kepala seksi dan anggota seksi tersebut. Namun, jika dilihat dari segi kenyamanan, Kantor Camat Tuahmadani masih kurang dalam memberikan kenyamanan, baik itu kenyamanan untuk para pegawainya maupun kenyamanan bagi masyarakat yang datang ke kantor. Hal ini dipengaruhi oleh masih kurangnya sarana prasarana di dalam kantor tersebut seperti belum adanya pintu kaca serta alat pendingin ruangan di ruang pelayanan Kantor Camat Tuahmadani serta masih belum adanya papan informasi, papan data, dan papan agenda sebagai sarana komunikasi dan transparansi atas kegiatan yang Kecamatan Tuahmadani laksanakan.

\section{Perubahan Sumber Daya Manusia}

Sumber daya manusia dalam organisasi merupakan salah satu aktor penting dalam keberhasilan organisasi dalam mewujudkan visi dan misi dari organisasi tersebut. Perubahan dalam lingkungan organisasi akibat dari adanya implementasi kebijakan juga dapat terjadi 


\section{Journal Publicuho}

ISSN2621-1351 (online), ISSN 2685-0729 (print)

Volume 4 Number 4 (November - January), (2021) pp. 1254-1271 Accredited SINTA SK.NOMOR 28/E/KPT/2019 Open Access at:http://ojs.uho.ac.id/index.php/PUBLICUHO/index $\quad$ DOI: http://dx.doi.org/10.35817/jpu.v4i4.22614

pada sumber daya manusia di dalam organisasi tersebut dalam penelitian ini adalah perubahan yang terjadi pada sumber daya manusia di Kecamatan Tuahmadani pasca kebijakan penataan kecamatan di Kota Pekanbaru di implementasikan. Sebelum adanya kebijakan penataan kecamatan, Kecamatan Tampan yakni induk dari Kecamatan Tuahmadani sebelum pemekaran memiliki pegawai yang lebih banyak. Hal ini dikarenakan dulunya Kecamatan Tampan memiliki 9 kelurahan dan memiliki jumlah masyarakat yang sangat banyak. Sehingga beban kerja dari pegawai kecamatan pun juga sangat banyak. Adapun jumlah pegawai Kecamatan Tampan sebagai induk Kecamatan Tuahmadani sebelum kebijakan penataan kecamatan diimplementasikan adalah sebagai berikut:

Tabel 1. Jumlah Pegawai Kecamatan Berdasarkan Golongan Tahun 2020

\begin{tabular}{ccc}
\hline No & Golongan & Jumlah \\
\hline 1. & Golongan I & - \\
\hline 2. & Golongan II & 2 \\
\hline 3. & Golongan III & 22 \\
\hline 4. & Golongan IV & 1 \\
\hline & Total & $\mathbf{2 5}$ \\
\hline
\end{tabular}

Sumber: Kecamatan Tampan Dalam Angka, 2021

Dari tabel diatas, dapat diketahui bahwa jumlah pegawai Kecamatan Tampan berdasarkan golongannya pada tahun 2020 adalah 25 orang, dengan rincian Golongan II sebanyak 2 orang, Golongan III sebanyak 22 orang, dan Golongan IV sebanyak 1 orang.

Tabel 2. Jumlah Pegawai Kecamatan Tampan Berdasarkan Strata Pendidikan Tahun 2020

\begin{tabular}{ccc}
\hline No & Strata Pendidikan & Jumlah \\
\hline 1. & SSMA & 11 \\
\hline 2. & DI/DII/DIII & 2 \\
\hline 3. & S1/DIV & 10 \\
\hline 4. & S2/S3 & 2 \\
\hline & Total & $\mathbf{2 5}$ \\
\hline & Sumber:Kecamatan Tampan Dalam Angka 2021
\end{tabular}

Sumber: Kecamatan Tampan Dalam Angka 2021

Dari tabel diatas, dapat dilihat bahwa jumlah pegawai Kecamatan Tampan berdasarkan strata pendidikan adalah 25 orang dengan rincian SSMA sebanyak 11 orang, DI/DII/DIII sebanyak 2 orang, S1/DIV sebanyak 10 orang, dan S2/S3 sebanyak 2 orang.

Setelah kebijakan penataan kecamatan diimplementasikan, hasilnya adalah Kecamatan Tampan dimekarkan menjadi Kecamatan Tuahmadani. Atas dasar hal tersebut, terjadi perubahan sumber daya manusia kecamatan. Dalam hal ini jumlah pegawai di Kecamatan Tuahmadani lebih sedikit dibanding kecamatan induknya dulu yaitu Kecamatan Tampan. Selain itu, juga terjadi perubahan kualitas dari sumber daya manusia atau pegawai Kecamatan Tuahmadani. Hal ini dapat dilihat dalam penyelenggaraan 
ISSN2621-1351 (online), ISSN 2685-0729 (print

Volume 4 Number4 (November - January), pp.1254-1271

Hafizh Ayyasy Habibi, Hasim As'ari DOI: http://dx.doi.org/10.35817/jpu.v4i4.22614

pemerintahannya Kecamatan Tuahmadani memiliki pegawai dengan uraian sebagai berikut:

Tabel 3. Jumlah Pegawai Kecamatan Tuahmadani Berdasarkan Golongan

\begin{tabular}{ccc}
\hline No & Golongan & Jumlah \\
\hline 1 & Golongan I & - \\
\hline 2 & Golongan II & 5 \\
\hline 3 & Golongan III & 15 \\
\hline 4 & Golongan IV & - \\
\hline & Total & $\mathbf{2 0}$ \\
\hline
\end{tabular}

Sumber: Olahan Peneliti, 2021

Dari tabel diatas, dapat dilihat bahwa jumlah pegawai Kecamatan Tuahmadani berdasarkan golongan adalah 20 orang, dengan rincian Golongan II sebanyak 5 orang dan Golongan III sebanyak 15 orang.

Tabel 4. Jumlah Pegawai Kecamatan Tuahmadani Berdasarkan Strata Pendidikan

\begin{tabular}{ccc}
\hline No & Strata Pendidikan & Jumlah \\
\hline 1. & S2 & 1 \\
\hline 2. & S1 & 8 \\
\hline 3. & D3 & 3 \\
\hline 4. & SMA & 8 \\
\hline & Total & $\mathbf{2 0}$ \\
\hline
\end{tabular}

Sumber: Olahan Peneliti, 2021

Berdasarkan sajian tabel diatas, dapat dilihat bahwasanya semenjak kebijakan penataan kecamatan di implementasikan, pegawai kecamatan mengalami perubahan dalam bentuk pengurangan dan kualitas dari pegawai tersebut. Sebelum terjadinya penataan kecamatan, pegawai di Kecamatan Tampan sebagai induk Kecamatan Tuahmadani sebelum pemekaran berjumlah 25 orang. Namun setelah adanya kebijakan penataan kecamatan yang mana Kecamatan Tampan dimekarkan menjadi Kecamatan Tuahmadani, Kecamatan Tuahmadani memiliki pegawai berjumlah 20 orang. Dari sajian tabel diatas juga dapat dilihat dari golongan dan strata pendidikannya memiliki jumlah yang berbeda yang menunjukkan adanya perubahan dalam kualitas pegawai di Kecamatan Tuahmadani. Mempertimbangkan kemampuan pegawai merupakan strategi yang harus diterapkan dalam menyusun struktur organisasi karena perubahan struktur berpengaruh besar pada harapan dan mentalitas pegawainya serta perubahan dalam sumber daya manusia itu sendiri. Dalam hal ini, perubahan struktur merupakan dampak dari adanya kebijakan penataan kecamatan sehingga perlu adanya strategi untuk menetapkan dan meletakkan sumber daya manusia atau pegawai yang handal untuk menempati struktur kecamatan tersebut. Hal ini seperti yang disebutkan oleh John P. Kotter bahwa perubahan haruslah memperhatikan kemampuan sumber daya manusianya (Amin \& Kumaradjaja, 2009:371). Namun dalam pelaksanaanya, Kecamatan Tuahmadani masih memerlukan pegawai 


\section{Journal Publicuho}

ISSN2621-1351 (online), ISSN 2685-0729 (print)

Volume 4 Number 4 (November - January), (2021) pp. 1254-1271 Accredited SINTA SK.NOMOR 28/E/KPT/2019 Open Access at:http://ojs.uho.ac.id/index.php/PUBLICUHO/index $\quad$ DOI: http://dx.doi.org/10.35817/jpu.v4i4.22614

tambahan di bagian pelayanan yang memiliki kompetensi sebagai operator komputer. Hal ini bertujuan untuk meningkatkan pelayanan. Karena apabila pegawai memiliki skill atau kompetensi yang dibutuhkan, maka pelayanan pun dapat meningkat hingga berkualitas serta menunjukkan kualitas dari pegawai Kecamatan Tuahmadani pula.

Peneliti menyimpulkan bahwasanya adaptasi dalam bentuk perubahan sumber manusia/pegawai masih belum maksimal. Hal ini dapat dilihat bahwa proses adaptasi yang dilakukan hanya mementingkan infrastruktur daripada keahlian dan kualitas dari pegawainya. Selain itu, dapat dilihat bahwasanya Kecamatan Tuahmadani masih membutuhkan pegawai tambahan dan pegawai yang memiliki kompetensi sebagai operator komputer. Sehingga dalam hal ini, Giddens dalam Winandri (2018:86) menyatakan bahwa adaptasi yang dilakukan haruslah menyeimbangkan dengan memperhatikan kualitas sumberdaya otoritatif (lingkungan atau manusia) dan infrastruktur fisik (alokatif)

\section{Hambatan Dalam Proses Adaptasi Penyelenggaraan Pemerintahan Kecamatan Tuahmadani}

Implementasi kebijakan penataan kecamatan berdasarkan Perda Kota Pekanbaru Nomor 2 Tahun 2020 menghasilkan beberapa kecamatan baru di Kota Pekanbaru, salah satunya adalah Kecamatan Tuahmadani. Sebagai kecamatan baru, diperlukannya adaptasi dalam penyelenggaraan pemerintahan. Namun, dalam pelaksanaanya, proses adaptasi yang dilakukan masih terdapat beberapa hambatan, diantaranya adalah sebagai berikut:

\section{Kodefikasi wilayah kecamatan baru belum terbit}

Peraturan Daerah Kota Pekanbaru Nomor 2 Tahun 2020 tentang Penataan Kecamatan di sahkan pada 13 Agustus 2020 lalu, dan di implementasikan dalam bentuk peresmian 3 (tiga) kecamatan baru di tanggal 30 Desember 2020 lalu. Pemerintah Kota Pekanbaru mengatakan bahwasanya Kementerian Dalam Negeri (Kemendagri) menjanjikan bahwasanya kodefikasi wilayah kecamatan baru ini akan terbit di awal tahun 2021, namun kenyataanya hingga akhir tahun ini kodefikasi tersebut belum juga diterbitkan oleh Kemendagri. Dilansir dari pekanbaru.go.id, bahwasanya kode wilayah tersebut sebenarnya sudah keluar, namun baru berupa pesan whatsapp saja sehingga kode wilayah tersebut belum dapat digunakan.

Hingga saat ini Pemerintah Kota Pekanbaru masih menunggu kode tersebut diterbitkan secara resmi melalui Peraturan Menteri Dalam Negeri (Permendagri). Setelah kode tersebut terbit secara resmi, barulah pelayanan perubahan administrasi kependudukan akan dibuka untuk masyarakat Pemerintah Kota Pekanbaru yang ingin mengurus peralihan data kependudukan dan mengurus data data kependudukan yang baru. Dalam hal ini, tentunya menjadi penghambat dalam proses adaptasi dalam penyelenggaraan pemerintahannya yang dilakukan oleh Kecamatan Tuahmadani yang disebabkan oleh 
ISSN2621-1351 (online), ISSN 2685-0729 (print

Volume 4 Number4 (November - January), pp.1254-1271

Hafizh Ayyasy Habibi, Hasim As'ari DOI: http://dx.doi.org/10.35817/jpu.v4i4.22614

kodefikasi wilayah yang belum kunjung terbit. Hal ini juga berdampak pada segala jenis pengurusan/pelayanan yang menggunakan atau mengambil data dari akta kependudukan seperti ktp/kk yang paling sering digunakan untuk mengurus surat-surat penting.

\section{Kurangnya ketersediaan infrastruktur dan sarana prasarana Kantor Camat Tuahmadani}

Kebijakan penataan kecamatan yang telah diimplementasikan menghasilkan Kecamatan Tuahmadani sebagai kecamatan baru menempati gedung/kantor baru yang terletak di ruko sewaan di Jalan raya Pekanbaru-Bangkinang (depan UIN SUSKA RIAU). Dalam pelaksanaanya, peneliti masih menemukan bahwa infrastruktur serta sarana prasarana di Kantor Camat Tuahmadani masih kurang. Terutama di bagian ruang pelayanan dimana sebagai tempat untuk memberikan pelayanan kepada masyarakat yang masih belum bisa memberikan kenyamanan bagi masyarakat dan kenyamanan pegawai kecamatan yang bekerja.

\section{Kurangnya ketersediaan sumber daya manusia/pegawai Kecamatan Tuahmadani dalam penyelenggaraan pemerintahan}

Dalam proses adaptasi penyelenggaraan pemerintahan, diperlukannya sumber daya manusia/pegawai yang cukup untuk menyelenggarakan pemerintahan. Dalam proses adaptasi yang dilakukan oleh Kecamatan Tuahmadani, peneliti menemukan bahwa pegawai Kecamatan Tuahmadani dalam penyelenggaraan pemerintahan masih kurang. Hal ini tentu menghambat segala kegiatan dalam penyelenggaraan pemerintahan Kecamatan Tuahmadani dan juga akan mempengaruhi produktivitas kinerja dari Kecamatan Tuahmadani.

\section{Upaya Yang Dilakukan Oleh Kecamatan Tuahmadani Dalam Mengatasi Hambatan Pada Proses Adaptasi Penyelenggaraan Pemerintahan Kecamatan}

Dari beberapa hambatan yang telah di jelaskan sebelumnya, berikut adalah upaya yang dilakukan oleh Kecamatan Tuahmadani dalam mengatasi hambatan pada proses adaptasi penyelenggaraan pemerintahan kecamatan:

\section{Menerbitkan dokumen kependudukan menggunakan data Kecamatan induk}

Implementasi kebijakan penataan kecamatan menyebabkan terjadinya perubahan dalam data kependudukan masyarakat. Dalam hal ini, masyarakat perlu melakukan pengurusan peralihan data kependudukan atau mengurus akta kependudukan yang baru. Namun dalam pelaksanaannya, hal tersebut belum bisa dilakukan dikarenakan kodefikasi wilayah kecamatan baru belum diterbitkan oleh Kementerian Dalam Negeri (Kemendagri). Berdasarkan hal tersebut, sebagai penyelenggara pemerintahan dalam pemberian pelayanan kepada masyarakat, Kecamatan Tuahmadani memberikan jalan keluar/solusi berupa penerbitan dokumen kependudukan menggunakan kecamatan induk dalam hal 


\section{Journal Publicuho}

ISSN2621-1351 (online), ISSN 2685-0729 (print)

Volume 4 Number 4 (November - January), (2021) pp. 1254-1271 Accredited SINTA SK.NOMOR 28/E/KPT/2019 Open Access at:http://ojs.uho.ac.id/index.php/PUBLICUHO/index $\quad$ DOI: http://dx.doi.org/10.35817/jpu.v4i4.22614

ini adalah Kecamatan Tampan dan juga segala urusan pelayanan masih diperbolehkan menggunakan data kependudukan yang lama (kecamatan induk).

\section{Mengajukan anggaran pembangunan dan kelengkapan sarana prasarana Kantor Camat Tuahmadani pada tahun 2022}

Dalam pemberian pelayanan kepada masyarakat, Kecamatan Tuahmadani dapat dikatakan belum cukup baik dalam pemberian pelayanan. Hal ini dapat dilihat dari masih adanya sarana prasarana di dalam kantor camat yang masih harus dilengkapi. Hal ini tentu akan mempengaruhi kinerja dari pegawai kecamatan serta kenyamanan dari masyarakat yang menjadi tolak ukur kualitas pelayanan kepada masyarakat. Dalam hal ini, upaya yang dilakukan oleh Kecamatan Tuahmadani yaitu dengan menganggarkan pembangunan dan kelengkapan sarana prasarana Kantor Camat Tuahmadani pada tahun 2022. Hal ini merupakan komitmen dan upaya dari Kecamatan Tuahmadani dalam memberikan pelayanan yang optimal kepada masyarakat dan sebagai wujud dari proses adaptasi penyelenggaraan pemerintahan yang baik.

\section{Mengajukan formasi pegawai kecamatan pada tahun 2022}

Dalam penyelenggaraan pemerintahan kecamatan, Kecamatan Tuahmadani masih kekurangan pegawai. Kecamatan Tuahmadani masih memerlukan tambahan pegawai di bagian pelayanan yang memiliki komptensi sebagai operator komputer. Untuk mengatasi hal tersebut, Kecamatan Tuahmadani berkomitmen untuk menambah pegawainya dengan mengajukan formasi pegawai yang dibutuhkan sesuai dengan kompetensi yang diperlukan. Hal ini juga sebagai upaya dalam meningkatkan kualitas pemberian pelayanan kepada masyarakat dan upaya dalam peningkatan kinerja dari pegawai Kecamatan Tuahmadani dalam proses adaptasi penyelenggaraan pemerintahan kecamatan.

\section{KESIMPULAN}

Dari hasil penelitian tentang adaptasi yang dilakukan Kecamatan Tuahmadani dalam penyelenggaraan pemerintah kecamatan pasca implementasi kebijakan penataan kecamatan di Kota Pekanbaru, maka dapat disimpulkan bahwa:

1. Proses adaptasi dalam penyelenggaraan pemerintah Kecamatan Tuahmadani belum berjalan dengan baik, hal ini dapat diketahui dari proses adaptasi pada:

a. Struktur, Kecamatan Tuahmadani memiliki kemauan atau komitmen untuk beradaptasi dengan struktur yang ditetapkan yang memiliki tugas pokok dan fungsi untuk menjalankan penyelenggaraan pemerintah kecamatan. Selain itu, struktur Kecamatan Tuahmadani yang telah ditetapkan berdasarkan Peraturan Walikota Pekanbaru Nomor 233 Tahun 2020 tentang Perubahan Kedudukan, Susunan Organisasi, Tugas Dan Fungsi Serta Tata Kerja Kecamatan di Lingkungan Pemerintah Kota Pekanbaru memiliki kesesuaian dengan 6 (enam) unsur dalam pembentukan struktur menurut Robbins. 
ISSN2621-1351 (online), ISSN 2685-0729 (print

b. Perubahan teknologi, Kecamatan Tuahmadani memiliki aplikasi SIPADU PATEN. Namun pada pelaksanaannya, aplikasi ini belum berjalan dengan baik. Hal tersebut disebabkan kurangnya sosialisasi kepada masyarakat terhadap penggunaan aplikasi tersebut dan juga kurangnya pegawai Kecamatan Tuahmadani yang memiliki kompetensi sebagai operator komputer.

c. Perubahan penataan fisik, proses adaptasi penataan fisik yang dilakukan oleh Kecamatan Tuahmadani sudah cukup baik, namun belum maksimal. Hal ini dapat dilihat dari masih ada sarana prasarana yang masih belum ada/kurang yang mempengaruhi kenyamanan dari pegawai Kecamatan Tuahmadani dalam bekerja dan masyarakat yang dilayani. Hal ini juga akan mempengaruhi kualitas pelayanan yang diberikan dan kualitas pelayanan yang didapatkan oleh masyarakat.

d. Perubahan sumber daya manusia, Kecamatan Tuahmadani lebih mementingkan infrastruktur daripada keahlian dari pegawainya. Hal ini dapat dilihat bahwasanya Kecamatan Tuahmadani masih membutuhkan pegawai yang memiliki kompetensi sebagai operator komputer. Sehingga adaptasi yang dilakukan haruslah menyeimbangkan dengan memperhatikan sumberdaya-sumberdaya otoritatif (lingkungan atau manusia) dan infrastruktur fisik (alokatif).

2. Hambatan yang peneliti temukan dalam proses adaptasi penyelenggaraan pemerintahan Kecamatan Tuahmadan adalah sebagai berikut:

a. Kodefikasi wilayah kecamatan baru yang belum terbit.

b. Kurangnya ketersediaan infrastruktur dan sarana prasarana Kantor Camat Tuahmadani.

c. Kurangnya sumber daya manusia/pegawai Kecamatan Tuahmadani dalam penyelenggaraan pemerintahan.

3. Upaya Yang Dilakukan Oleh Kecamatan Tuahmadani Dalam Mengatasi Hambatan Pada Proses Adaptasi Penyelenggaraan Pemerintahan Kecamatan adalah sebagai berikut:

a. Menerbitkan dokumen kependudukan menggunakan data Kecamatan induk

b. Mengajukan anggaran pembangunan dan kelengkapan sarana prasarana Kantor Camat Tuahmadani pada tahun 2022.

c. Mengajukan formasi pegawai kecamatan pada tahun 2022 


\section{Journal Publicuho}

ISSN2621-1351 (online), ISSN 2685-0729 (print)

Volume 4 Number 4 (November - January), (2021) pp. 1254-1271 Accredited SINTA SK.NOMOR 28/E/KPT/2019 Open Access at:http://ojs.uho.ac.id/index.php/PUBLICUHO/index $\quad$ DOl: http://dx.doi.org/10.35817/jpu.v4i4.22614

\section{REFERENSI}

Amin, M., \& Richard Kumaradjaja. (2009). Strategi Change Management Untuk Mempercepat Implementasi Penggunaan Aplikasi Perangkat Lunak Berbasis Open Source: Studi Kasus Kementerian Negara Riset Dan Teknologi. Journal Of Business Strategy And Execution, 1 (2), 366-386.

Creswell, J. W. (2015). Penelitian Kualitatif \& Desain Riset: Memilih Di Antara Lima Pendekatan. Yogyakarta: Pustaka Pelajar.

Joaquin, M. E. (2009). Bureaucratic Adaptation And The Politics Of Multiple Principals In Policy Implementation. American Review Of Public Administration, 39(3), 246-268. Https://Doi.Org/10.1177/0275074008319622

Maksudi, B. I. (2018). Dasar-Dasar Administrasi Publik: Dari Klasik Ke Kontemporer. Depok: Rajawali Pers.

Muhammad Elwan, L. O. (2020). ANALISIS KEBIJAKAN PAJAK DAERAH SEBAGAI SUMBER PENDAPATAN ASLI DAERAH KABUPATEN KOLAKA TIMUR DI ERA OTONOMI DAERAH. Journal Publicuho. https://doi.org/10.35817/jpu.v3i2.12529

Nurasa, H. (2013). Analisis Organisasi Pemerintah Daerah Khusus Ibukota Jakarta Sebagai Sebuah Sistem Terbuka. Sosiohumaniora, 15(1), 80-90. Https://Doi.Org/10.24198/Sosiohumaniora.V15i1.5242

Robbins, S. P. (2001). Organizational Behavior (9th Ed.). New York: Prentice-Hall.

Sarta, A., Durand, R., \& Vergne, J. P. (2021). Organizational Adaptation. Journal Of Management, 47(1), 43-75. Https://Doi.Org/10.1177/0149206320929088

Siahaan, A., \& Zen, W. L. (2012). Manajemen Perubahan (Telaah Konseptual, Filosofis Dan Praktis Terhadap Kebutuhan Melakukan Perubahan Dalam Organisasi) (T. Rafida, Ed.). Bandung: Citapustaka.

Smith, T. B. (1973). The Policy Implementation Process. Policy Sciences, 4(2), 197-209. Https://Doi.Org/10.1007/Bf01405732

Sunandar, A. (2012). Keterhubungan Struktur Dengan Budaya Organisasi. Manajemen Pendidikan, 23(5), 403-413.

Supriadin, R., Alam, S., \& Elwan, L. O. M. (2020). IMPLEMENTASI PERATURAN WALIKOTA KENDARI NOMOR 13 TAHUN 2008 TENTANG PENATAAN PEDAGANG KAKI LIMA DI KOTA KENDARI. Journal Publicuho. https://doi.org/10.35817/jpu.v3i1.11506

Syadzily, A. H. (2019). Desentralisasi, Otonomi, Dan Pemekaran Daerah Di Indonesia. Prenadamedia Group.

Winandri, A. A. (2018). Adaptasi Dinas Komunikasi Dan Informatika Kabupaten Deli Serdang Terhadap Perkembangan Teknologi Informasi Dan Komunikasi (Tik) Dalam Mewujudkan E- Government. Universitas Sumatera Utara. 